\title{
The advantages of modified air plasma jet method in the process of deposition of hydroxyapatite coatings on the titanium surface
}

\begin{abstract}
The advantages of modified plasma jet construction and its main characteristics were investigated in the process of the hydroxyapatite (CHA) deposition on the surface of titanium substrate. Calculation of the CHA particles velocity and residence time inside of plasma torch PJ-100 were made. The depth of CHA coating, its morphology and its bond with the titanium substrate were investigated. Special care was paid to the extraordinary coating adhesion properties. All the obtained results showed that this plasma jet installation and process of deposition are very promising for obtaining satisfying coatings on the implants for hips, knees and teeth.
\end{abstract}

Keywords: hydroxyapatite coatings, air plasma jet, titanium substrate, orthopedic application

\section{INTRODUCTION}

Hydroxyapatite (CHA, having chemical formula $\left.\mathrm{Ca}_{10}\left(\mathrm{PO}_{4}\right)_{6}(\mathrm{OH})_{2}\right)$ is a bioactive ceramics which due to chemical composition and crystal structure similar to those of natural bone can facilitate integration of prostheses into osseous tissue [1, 2]. Because of its limited mechanical strength, CHA is used as coating on surfaces of more resistant metallic prostheses made of, e.g., Ti-alloys [3, 4]. The environment rich with calcium and phosphate ions at the surface of prosthesis favors proliferation of bone cells and enhances its adhesion to the bone $[5,6]$. Therefore, recently, many innovative approaches of deposition of hydroxyapatite coatings on the surface of mechanically strong metallic substrates to enhance their osseointegration were developed, such as sol-gel, chemical deposition, ion-sputtering deposition, thermal spraying and particularly atmospheric and high vacuum plasma spraying technique [7-9].

As it was shown in our recent investigations, during the atmospheric plasma spraying process, hydroxyapatite agglomerates with smaller particles incorporated inside of them were melted on their surfaces and rapidly re-solidified on the substrate to form splats [10]. Crystallinity of starting powder, the agglomerates size and surface temperature of the substrate, besides the plasma temperature and plasma velocity were shown as the most important factors which influence the coating crystallinity and its adhesion properties.

Author address: ${ }^{1}$ University of Belgrade, Vinča Institute of Nuclear Sciences, Belgrade, ${ }^{2}$ Institute of Chemistry, Technology and Metallurgy, Belgrade, ${ }^{3}$ University of Maribor, Faculty of Mechanical Engineering, Maribor, Slovenia, ${ }^{4}$ Zlatarna Celje d.d., Celje, Slovenia

Paper received: 27. 01. 2015.

Paper accepted: 22. 03. 2015.
The motion and heating of feedstock particles in air plasma jet are crucial for process efficiency and coating quality. The particles need to be treated in a specific process window of thermal and kinetic energy. The temperature of plasma should be generally above the melting point but below the decomposition point, while the velocity has to be sufficient to produce particle flow with predictable splashing during the impact with the substrate. This process is very complex, with numerous processing parameters that affect the coating quality. Nevertheless all of them can be classified into five groups according to their origin: i) the plasma torch which produces the plasma stream; ii) the powder injector which controls the powder feed rate, the injection position, angle and velocity; iii) the plasma itself, including gas composition, heat content, temperature, velocity and air dilution; iv) the powder particles, including particle shape and size distribution, elemental distribution within particles, and their residence time in the plasma stream; v) the substrate, including temperature, thermal expansion coefficient and conductivity [10].

Beside the parameters of the plasma jet deposition, the substrate preparation before $\mathrm{CHA}$ deposition is very important factor for coatings quality. Chemical treatment of the titanium substrate surface, to obtain very thin titanium oxide film consisting of gradient layers of different chemical composition, from the top layer with maximal oxygen content to the deepest and almost unchanged layer, showed to be very efficient [11]. This provides not only significantly better adhesion of CHA coating, but also stepwise transition between $\mathrm{Ti}$ metallic implant and $\mathrm{TiO}_{2}$ coating, inducing its enhanced adhesion and corrosion properties.

Such coatings obtained by an improved plasma jet method are expected to have better biocompatibility, particularly in case of its application on prostheses for hips, knees and on dental implants. 
Therefore, different characteristic of this plasma installation and the method of deposition are particularly discussed and corresponding calculations are given in theoretical part.

\section{THEORETICAL PART}

\subsection{The tehnical and thermal characteristic of plasma jet instalation PJ-100}

The construction of PJ-100 plasma installation, used in this study, is flexible and can provide a wide range of enthalpies of the generated plasma [12]. Two different nozzles can be applied, with working parameters given in Table 1: current intensity (I), power of plasma jet (P), the plasma enthalpies generated by $10 \mathrm{~mm}$ diameter anode nozzle and $106 \mathrm{~L} \mathrm{~min}^{-1}$ flow rate of argon, values for effective exhaust plasma velocity $\left(v_{\mathrm{e}}\right)$ and estimated values for the sound velocity of the plasma jet $\left(\mathrm{a}_{0}\right)$.

Table 1 - Working parameters of PJ-100 torch for conical and cylindrical anode nozzle

\begin{tabular}{|l|c|c|}
\hline Parameters & Conical nozzle & Cylindrical nozzle \\
\hline $\mathrm{I}_{\max }, \mathrm{A}$ & 480 & 498 \\
\hline $\mathrm{P}_{\max }, \mathrm{kW}$ & 90 & 91.1 \\
\hline $\mathrm{H}, \mathrm{MJ} \mathrm{kg}^{-1}$ & 23.2 & 23.3 \\
\hline $\mathrm{v}_{\mathrm{e}} \mathrm{m} \mathrm{s}^{-1}$ & $1127 \pm 45$ & $1579 \pm 63$ \\
\hline $\mathrm{a}_{0}, \mathrm{~m} \mathrm{~s}^{-1}$ & 2405 & 2396 \\
\hline
\end{tabular}

The thermal efficiency of the plasma gun is very high, between 70 and $74 \%$. Although it would be expected that the thermal loss would increase with the increase of the arc length, because of an enlarged nozzle surface exposed to hot plasma, the estimated thermal efficiency of this plasma torch is much higher than that of the conventional one and remains practically unchanged in a wide range of working powers tested.

The velocity of the cathode jet $\left(v_{\mathrm{CJ}}\right)$ can be estimated using eq.(1):

$$
v_{C J}=\frac{I \sqrt{\frac{\mu_{0}}{2 \rho}}}{\pi b},
$$

where $\mathrm{I}=500 \mathrm{~A}, \mu_{0}=1.2610^{-6} \mathrm{~N} \mathrm{~A}^{-2}, \rho$ is plasma density in $\mathrm{kg} / \mathrm{m}^{3}$ and $b=1.510^{-3} \mathrm{~m}$ is arc radius of the cathode. After corresponding calculation of plasma velocity, $\mathrm{v}_{\mathrm{Cl}}$ shows the value higher than $200 \mathrm{~m} \mathrm{~s}^{-1}$, which is many times higher than the gas velocity in the cathode section. In PJ-100 installation, the axially directed cathode jet is directed by vortex inlet of the cold gas and the walls of the anode channel, maintaining the arc in the axis of the anode channel.
Plasma torch possesses fixed minimal arc length, achieved by a cylindrical electrically neutral cooper nozzle - neutrode inserted between the cathode and the anode. Gas is introduced in a vortex regime into the space between the cathode and the neutrode. The neutrode is separated from the anode nozzle by $\mathrm{mm}$ thick ceramic insulating ring. The distance between the cathode tip and the anode opening is $32 \mathrm{~mm}$, and the length of anode is $30 \mathrm{~mm}$. The anode, the neutrode and the cathode are all water cooled.

In was shown in the previous investigations that cylindrical nozzle generates a faster plasma $\left(v \approx 1800 \mathrm{~m} \mathrm{~s}^{-1}\right)$ in comparison with the conical nozzle $\left(v \approx 1450 \mathrm{~m} \mathrm{~s}^{-1}\right)$. The same trend was obtained with a measured effective exhaust thrust velocity, which was $v e \approx 1600 \mathrm{~m} \mathrm{~s}^{-1}$ for the cylindrical and $v e \approx 1100 \mathrm{~m} \mathrm{~s}^{-1}$ for the conical nozzles. The velocity of sound of plasma jet was about 2300 $\mathrm{m} \mathrm{s}^{-1}$.

The plasma temperature and velocity were investiagted using photographs of the plasma taken by an IMACON790 electronic camera with a $1 \times 106$ plug-in module, which enables taking 106 photographs per second, with an exposure time of $200 \mathrm{~ns}$. For any new chosen geometry of shooting (the camera positioning to the plasma plume and zooming) a calibrating photograph was made. Six to eight successive shots, with $1 \mathrm{~s}$ time lapse between the two consecutive shots, were taken. The photographs were small $\left(16 \times 18 \mathrm{~mm}^{2}\right)$, and their analysis was possible only after careful computer processing, a procedure which enabled the choice of the best contrast and appropriate enlargement (4x) for further analysis of the photographs. This method of photographing the plasma plume allowed the estimation of the plasma speed in parts of the plasma plume in which it was possible to discriminate from the brighter to the darker zones, i.e. zones of different temperatures.

\subsection{Calculation of the $\mathrm{CHA}$ particles velocity and residence time inside of plasma torch $P J-100$}

In order to calculate the particles velocity and the residence time, the velocity of carrier gas in the hose should be determined firstly using eq.(2) [13]:

$$
U_{h-c g}=\frac{4 q_{c g}}{\pi D_{h}^{2}},
$$

where $q_{c g}$ is flow rate and $D_{h}$ is hose diameter.

The residence time in hose is given by the eq.(3):

$$
t_{h}=\sqrt{\frac{2 L_{h}}{k U_{h-c g}}}
$$

where $L_{h}$ is hose length and $k$ is defiend as: 


$$
k=\frac{18 \eta_{c g}}{\rho_{p} d_{p}^{2}},
$$

where $\eta_{c g}$ is dynamic viscosity of the carrier gas, $\rho_{p}$ is density of particle material and $d_{p}$ is particle diameter. The particle velocity at the end of the hose is given by eq.(5):

$$
U_{h-p}=U_{h-c g}\left(1-e^{-k t_{h}}\right),
$$

while the residence time of the particle in the injector $t_{i}$ is:

$$
t_{i}=\frac{\left(\sqrt{\left.U_{h-p}^{2}+2\left(U_{i-c g}-U_{h-p}\right) L_{i} k\right)}-U_{h-p}\right.}{k\left(U_{i-c g}-U_{h-p}\right)},
$$

where $L_{i}$ is injector length and $U_{i-c g}$ is the carrier gas velocity in the injector given by:

$$
U_{i-c g}=\frac{4 q_{c g}}{\pi D_{i}^{2}},
$$

where $D_{i}$ is injector diameter.

Finally, initial velocity of the particle in plasma jet is given by the following expression:

$$
U_{i-p}=U_{i-c g}-\left(U_{i-c g}-U_{h-p}\right) e^{-k t_{i}} .
$$

\section{MATERIALS AND METHODS}

To improve the adhesion of the CHA coating $\mathrm{Ti}$ substrate (DC titan, Bien-Air Medical Technologies, Switzerland) in the form of disks (diameter $10 \mathrm{~mm}$, height $2 \mathrm{~mm}$ ) was firstly roughened in the homemade chamber for roughening [12]. The specimens were then alkali etched in $5.0 \mathrm{ml}$ of $5 \mathrm{M} \mathrm{NaOH}$ aqueous solution for $24 \mathrm{~h}$ and then thermally treated at $500{ }^{\circ} \mathrm{C}$ for 5 hours [10]. An untreated sample was used as a control.

The previously described plasma installation PJ-100 was used for the deposition of CHA coatings on so prepared substrate. CHA powder (Captal ${ }^{\circledR}$ 90, Plasma Biotal Limited, UK) was used for deposition. The basic parameters during the plasma deposition were: plasma power $52.0 \pm 1.5 \mathrm{~kW}$, voltage $120 \pm 2 \mathrm{~V}$, current $430 \pm 5 \mathrm{~A}$, argon flow $38.5 \pm 1.2 \mathrm{~L} / \mathrm{min}$, powder carrier gas (air) $8 \mathrm{~L} / \mathrm{min}$ and powder feed rate $2.0 \pm 0.1 \mathrm{~g} / \mathrm{s}$. The diameter of aperture of the anode nozzle was 8 $\mathrm{mm}$, while the length of plasma jet was between 60 and $70 \mathrm{~mm}$. The spraying process was controlled by a computer - driven device. The nozzle moved parallel to the surface of the $\mathrm{Ti}$ samples with the velocity of $0.5 \mathrm{~cm} / \mathrm{s}$. The applied voltage regulated the temperature of the $\mathrm{Ti}$ substrate preheated to $200{ }^{\circ} \mathrm{C}$ [12], but various temperature regimes existed simultaneously on the substrate surface during spraying. However, the periodic motion of the spraying spot (diameter about of $1.5 \mathrm{~cm}$ ) over the surface heated up corresponding areas of the substrate significantly. When the spraying spot was moved, the temperature of the substrate was reestablished quickly to the initial value. This property enabled formation of almost uniformly thick coatings with a roughness very similar to that obtained by prior grit blasting of the substrate surface [10].

For adhesion strength measurements the $\mathrm{CHA}$ coated Ti substrate was welded to the top part of a cylinder $(25.0 \mathrm{~mm} \times 70 \mathrm{~mm})$ made of the SS AISI 316 LVM material. Adhesion strength was measured according to the ASTM C 633 Standard using an Instron 1185 machine. Five specimens were tested using the Klebbi adhesive (Metco, USA) polymerized for $2 \mathrm{~h}$ at $180^{\circ} \mathrm{C}$.

$\mathrm{X}$-ray Diffraction (XRD) patterns of the obtained $\mathrm{CHA}$ coatings were recorded in the range $15-65^{\circ}$ on a Siemens D500 diffractometer using $\mathrm{Cu} \mathrm{K \alpha 1}$ radiation. Quantitative analysis was made by an external standard method, according to the ASTM F 2024-00 Standard [14]. The amount of the amorphous phase was obtained by subtracting the sum of all the detected crystalline phases from 100 $\%$. [10]

The EDS, Energy Dispersive X-ray Spectrometer INCA Energy 450 and WDS wave dispersive spectrometer INCA Energy 700, of Oxford Instruments added to the Scanning Electron Microscope Jeol JSM 6500F were used for the estimation of CHA coating, investigations of coating morphology and chemical analysis through coating cross section. Prior to SEM examination the $\mathrm{CHA}$ cross sections of the samples were coated with an ultrathin film of carbon, using the Gatan 682, PECS (Precision Etching Coating System). The SEM was equipped additionally with a backscattered electron detector which enables BE images, operating at an accelerating voltage of $15 \mathrm{kV}$.

\section{RESULTS AND DISCUSSION}

\subsection{Calculation of the CHA particles velocity and residence time inside of plasma torchAPJ-100}

After replacement the values of hose diameter $D_{h}=3 \mathrm{~mm}$ and flow rate of $\mathrm{Ar}$ carrier $q_{c g}=38.5 \mathrm{I} / \mathrm{min}$ in eq.(2) the velocity of carrier gas inside of hose was calculated to be $91 \mathrm{~m} / \mathrm{s}$. Taking into account the values of dynamic viscosity of carrier gas at temperature close to $10000 \mathrm{~K}$ and higher: $\eta_{c g}=2.510^{-4} \mathrm{~kg} / \mathrm{m} \mathrm{s}$, particle density - the density of sprayed spherical agglomerates $\rho_{p}=2.52 \mathrm{~g} / \mathrm{cm}^{3}$ and particle diameter $d_{p}=90 \mathrm{~m}$, constant $\mathrm{k}$ was obtained using eq.(3). Using so obtained value for $k$ and previously obtained value for velocity of carrier gas inside of hose, for the hose length of 1.5 $\mathrm{m}$ the obtained residence time of particle in the 
hose was $1.210^{-5} \mathrm{~s}$. The residence time of particle in the injector, obtained using eq.(6), was almost the same. The initial and final velocities of particle in the plasma jet were almost equal, because the correction values obtained using eq. (6) and (8) can be neglected.

\subsection{Adhesive strength measurements}

The adhesive strength the CHA coatings was measured after plasma jet deposition at stand-off distances (SOD) of $80 \mathrm{~mm}$. Due to the high powder mass input $(2 \mathrm{~g} / \mathrm{s})$ and oscillatory movements of the plasma gun (about $\pm 25 \mathrm{~mm}$ with respect to the specimen centre) the highest thickness of the $\mathrm{CHA}$ coating was obtained in the middle of the specimen. The thickness of the obtained $\mathrm{CHA}$ coatings on Ti substrate was $152.4 \pm 19.8 \mathrm{~m}$. The adhesion strength measurements were performed according to the procedure described in the reference of Vilotijević et al. [14]. The obtained value of adhesion strength was $62.5 \pm 8.5 \mathrm{MPa}$.

\section{3. $X R D$ coatings deposited by plasma jet}

The sample showed the peaks at the angles characteristic for hydroxyapatite (Fig.1). From the $\mathrm{XRD}$ data it appears that hydroxyapatite is the only crystalline phase which is very important for its potential application because other crystalline calcium phosphate phases increase the coating degradation rate and weakening of its adhesive properties in service. On the other hand, it is very important to control the amount of amorphous calcium phosphate (ACP) phase obtained by plasma jet deposition, which dissolves rapidly in vitro and in vivo ( $<25 \%$ is the optimal level) [15]. The content of ACP phase was estimated in the range $2 \theta=20-40^{\circ}$ because the broad $A C P$ pick appears in this range in the XRD pattern [16] and the obtained value was $23 \pm 5 \%$. The value of crystallite size $(15.5 \mathrm{~nm})$ for showed that the hydroxyapatite coatings consist of nano-metric crystallites.

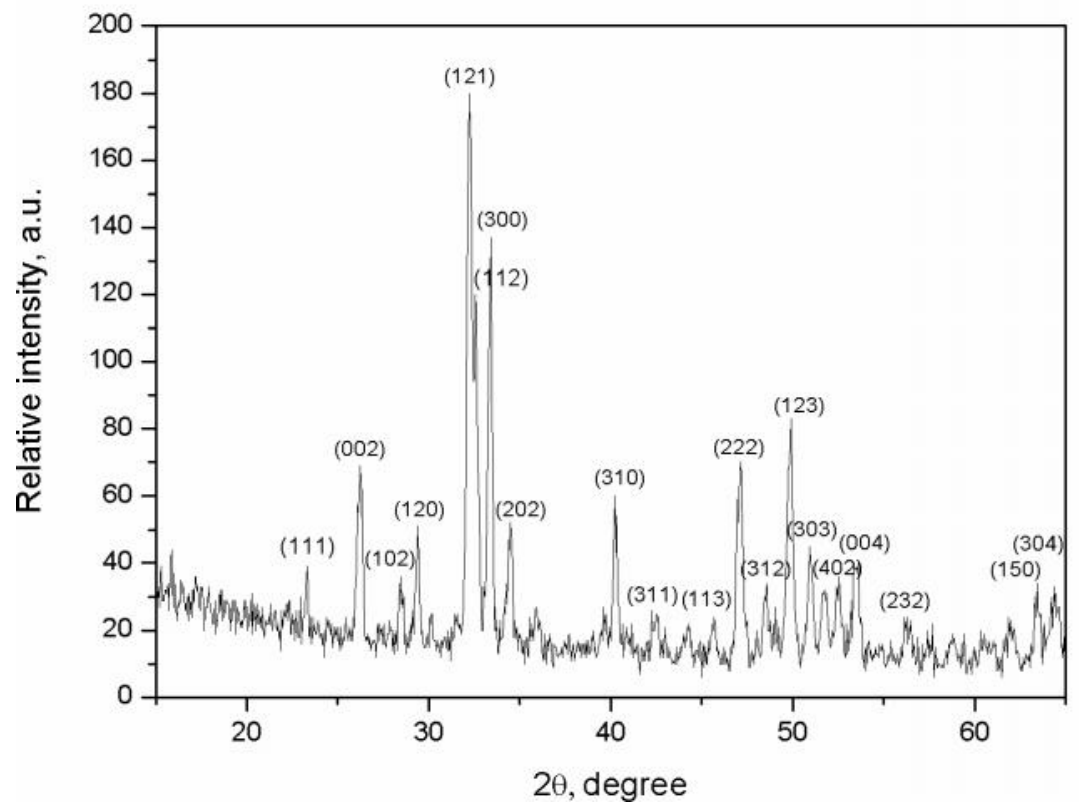

Figure 1 - XRD pattern of the CHA coating on the Ti substrate

\subsection{EDS and SEM analysis}

The EDS analysis of the CHA coating (Fig.2) showed the presence of all expecting elements, present from the titanium substrate surface to the top of the coating. The boundary between the $\mathrm{Ti}$ substrate and the CHA coating was clearly visible. A small quantity of oxygen was noticed, while the $\mathrm{Ti}$ concentration deceased to a zero value. Small quantities of calcium and phosphorous were registered on the left side of the boundary. The oxygen level was between 3.9 mass $\%$ at a distance of $5.4 \mathrm{~m}$ left from the substrate boundary and 39.1 mass $\%$ at the boundary. The mixing of ions from the right and left side of the boundary was clearly visible at a distance of $1.8 \mathrm{~m}$ left from the boundary. The maximal depth of penetration of $\mathrm{Ca}$ and $\mathrm{P}$ ions were about $3.8 \mathrm{~m}$ inside of the substrate depth. Inside the $\mathrm{CHA}$ coating at a distance of $1.8 \mathrm{~m}$ on the right there is no more interference (mixing) of ions from the $\mathrm{Ti}$ substrate with the ions present in the CHA coating. In deeper layers of the $\mathrm{CHA}$ coating the concentration of $\mathrm{Ca}$, $P$ and $O$ ions reached saturation, becoming uniform with further increasing of distance. 


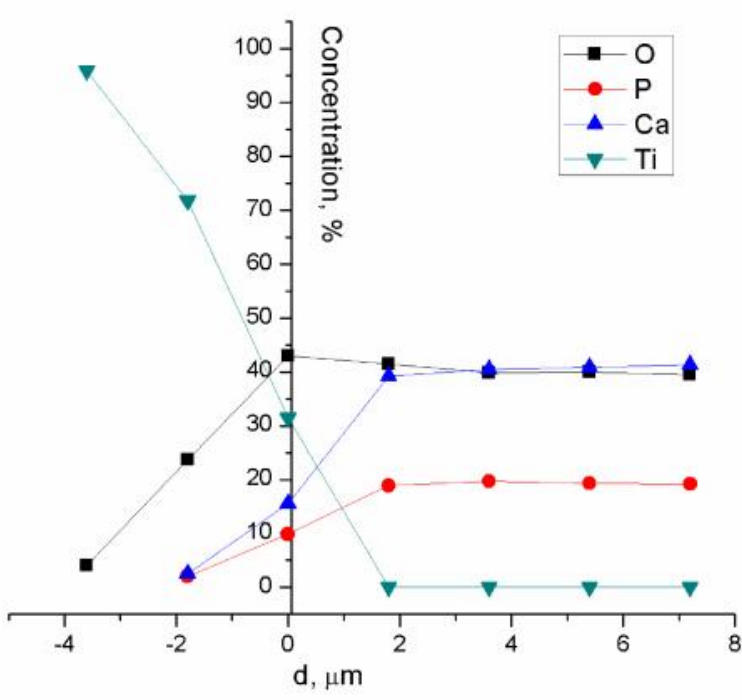

Figure 2 - EDS of cross section of CHA coatings depending on the distance from one side of the boundary (left) or the other (right) and typical appearance of its surface

From the aspect morphology, the CHA coating has very rough surface (Fig.3), which is suitable for cell adhesion. All these facts show that this coating with extraordinary high adhesion strength and suitable morphology for cell attachment has very promising properties to be used as further implant coating to enhance contact with surrounding biological tissues.

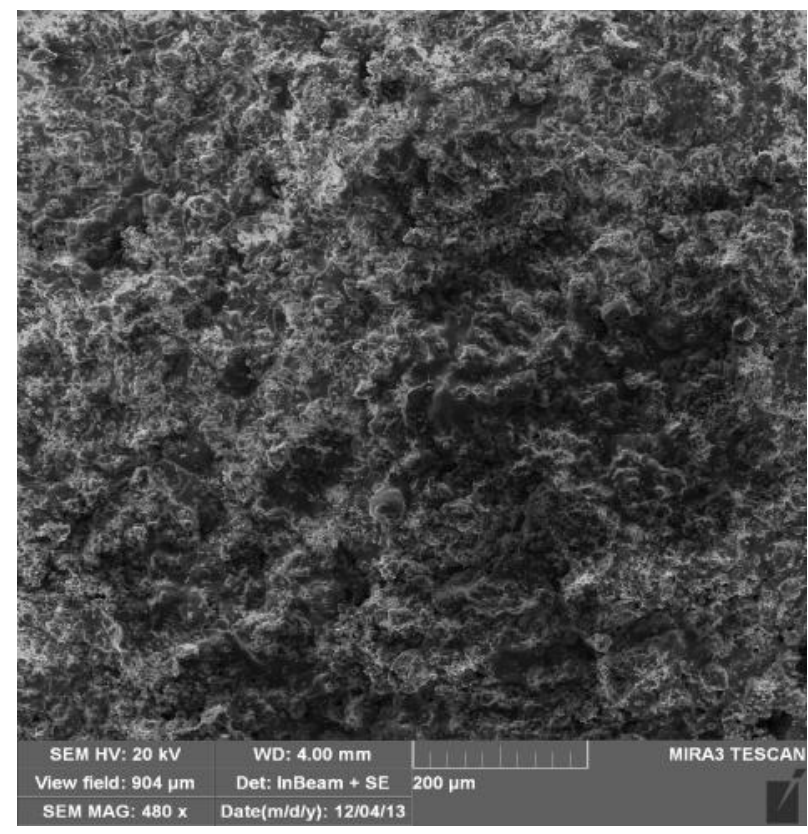

Figure 3 - SEM micrographs of the CHA coating on the Ti substrate

\section{CONCLUSIONS}

The advantages of the atmospheric plasma jet installation PJ-100 were described in this paper. All characteristic parameters including unusually long length of plasma jet $(70 \mathrm{~mm}$; i.e. twice higher than plasma jet length of the conventional PJ) and high radial and axial plasma temperature homogeneity (evident from the brightness distribution), as well as the laminar plasma flow along $2 / 3$ of its length from the anode nozzle exit and significantly higher plasma velocity then in any known plasma jet equipment were discussed. The calculation of the $\mathrm{CHA}$ particles velocity and residence time inside of plasma torch PJ-100 was also done.

The obtained $\mathrm{CHA}$ coating on Ti substrate had a thickness of $152.4 \pm 19.8 \mathrm{~m}$ and showed extraordinary high adhesive strength of $62.5 \pm 8.5$ $\mathrm{MPa}$. Its morphology seems to be suitable for cell attachment. Quantitative phase analysis showed uniform concentration of $\mathrm{Ca}, \mathrm{P}$ and $\mathrm{O}$ ions in layers close to boundary layer with the substrate and further.

\section{Acknowledgements}

This work was supported by the Ministry of Education, Science and Technological Development of the Republic of Serbia (Project 172026) and EUREKA Program CELL-TI E!5831.

\section{REFERENCES}

[1] A. Lugovskoy, S. Lugovskoy (2014) Production of hydroxyapatite layers on the plasma electrolytically oxidized surface of titanium alloys, Mater. Sci. Eng. C 43, 527-532.

[2] N. Metoki, L. Leifenberg-Kuznits, W. Kopelovich, L. Burstein, M. Gozin, N. Eliaz (2014) Hydroxyapatite coatings electrodeposited at near-physiological conditions, Mater. Lett. 119, 24-27.

[3] M. Niinomi (1998) Mechanical properties of biomedical titanium alloys, Mater Sci Eng A 243, 231-236.

[4] M. Geetha, A.K. Singh, R. Asokamani, A.K. Gogia, $\mathrm{Ti}$ based biomaterials, the ultimate choice for orthopaedic implants - A review. Prog Mater Sci 54: 397-425

[5] R. Palanivelu, S. Kalainathan, A. Ruban Kumar (2014) Characterization studies on plasma sprayed (AT/HA) bi-layered nano ceramics coating on biomedical commercially pure titanium dental implant, Ceram. Int. 40, 7745-7751.

[6] R. Drevet, A. Viteaux, J. C. Maurin, H. Benhayoune (2013) Human osteoblast-like cells response to pulsed electrodeposited calcium phosphate coatings, RSC Advances 3, 11148-11154.

[7] G. Wang, H. Zreiqat (2010) Functional Coatings or Films for Hard-Tissue Applications, Materials 3, 3994-3950. 
[8] X. Liu, P. K. Chu, C. Ding (2004) Surface modification of titanium, titanium alloys, and related materials for biomedical applications, Mater. Sci. Eng. R 47, 49-62.

[9] P. K. Huang, J. W. Yeh, T. T. Shun, S. K. Chen (2004) Multi-Principal-Element Alloys with Improved Oxidation and Wear Resistance for Thermal Spray Coating, Adv.Eng.Mater. 6, 74-78

[10] V. Jokanović, M. Vilotijević, B. Čolović, M. Jenko, I. Anžel, R. Rudolf (2014) Enhanced adhesion properties, structure and sintering mechanism of hydroxyapatite coatings obtained by plasma jet deposition, Plasma Chem. Plasma Process. ,article in press.

[11] V. Jokanović, M. Vilotijević, B. Jokanović, M. Jenko, I. Anžel, D. Stamenković, V. Lazic, R. Rudolf (2014) Investigations of corrosion on the surface of titanium substrate caused by combined alkaline and heat treatment, Corrosion Science 82 , 180-190.
[12] M. Vilotijević, B. Dačić, D. Božić (2009) Velocity and texture of a plasma jet created in a plasma torch with fixed minimal arc length, Plasma Sources Sci. Technol. 18, 015016.

[13] K. A. Gross, M. R. Phillips (1998) Identification and mapping of the amorphous phase in plasmasprayed hydroxyapatite coatings using scanning cathodoluminescence microscopy, J. Mater. Sci. Mater. Med 9, $797-802$.

[14] M. Vilotijević, P. Marković, S. Zec, S. Marinković, V. Jokanović (2011) Hydroxyapatite coatings prepared by a high power laminar plasma jet, J.Mater.Process.Technol. 211, 996-1004.

[15] S. Dyshlovenko, B. Pateyron, L. Pawlowski, D. Murano (2004) Numerical simulation of hydroxyapatite powder behaviour in plasma jet, Surf. Coat. Technol. 179, 110-117.

[16] K.A. Gross, M. R. Phillips (1998) Identification and mapping of the amorphous phase in plasmasprayed hydroxyapatite coatings using scanning cathodoluminescence microscopy, J. Mater. Sci. Mater. Med. 9, 797 - 802.

\title{
IZVOD
}

\author{
PREDNOSTI MODIFIKOVANE VAZDUSNE PLAZMA MLAZ METODE U PROCESU \\ TALOZENJA HIDROKSIAPATITNIH PREMAZA NA POVRSINI TITANIJUMA
}

U radu su istraživane prednosti modifikovanog uređaja za plazma sprejovanje u mlazu, uslovljene specifičnim karakteristikama plazma uređaja, u procesu depozcije kalcijum hidroksiapatita (CHA) na površini titanijum supstrata. Određena je brzina CHA čestica i vreme njihovog boravka u plazma torusu PJ-100 uređaja. Dubina prevlake CHA, njena morfologija i adhezivna veza sa titanijumskom podlogom, posebno su ispitivani. Izuzetna pažnja je posvećena adhezivnim osobinama ovih prevlaka, koje su bolje od svih dosada publikovanih u svetskoj literature. Svi dobijeni rezultati pokazali su da ovako modifikovana plazma instalacija i proces depozicije su veoma obećavajući za dobijanje vrlo kvalitetnih prevlaka na titanovim implantima za kukove, kolena i zube.

Ključne reči: hidroksiapatit premazi, vazdusna plazma mlaz, titanijum podloga, ortopedska aplikacija.

${ }^{*}$ Rad je saopsten na skupu ROSOV PIN 2014.

Pregledni rad

Rad primljen: 27. 01. 2015.

Rad prihvacen: 22. 03. 2015. 